J. Reprod. Fert. (1968) 15, 153-155

\title{
PREVENTION OF COAGULATION IN MONKEY SEMEN BY SURGERY
}

\author{
W. E. GREER*, J. D. ROUSSEL $\dagger$ AND G. R. AUSTIN $\ddagger$ \\ Delta Regional Primate Research Center, Covington, Louisiana, U.S.A.
}

(Received 28th Fuly 1967)

Monkey semen characteristically coagulates during ejaculation, and samples obtained by electrical stimulation consist wholly or largely of a rubbery mass. Some spontaneous dissolution occurs when the ejaculate is held in vitro at room or body temperature, but more than half the mass, usually about $75 \%$, remains unchanged. Use of monkey semen for laboratory studies or for artificial insemination is hampered by this feature. To some extent, the trouble can be remedied by the use of proteolytic enzymes, of which trypsin seems to be the least deleterious to sperm viability (Roussel \& Austin, 1967), but the presence of trypsin raises problems for many biochemical studies. Accordingly, the possibility was investigated that surgical removal of the coagulum-producing gland from the male tract might result in the ejaculation of coagulum-free semen, without seriously interfering with the volume and other semen characteristics, or the ease with which ejaculation can be artificially provoked.

Van Wagenen (1936) identified the cranial prostate gland as the source of the seminal coagulum by noting that a mixture of the secretions of this gland and of the seminal vesicle in the rhesus monkey produced a firm white coagulum. Mixing the secretion of the caudal prostate gland with seminal vesicle fluid did not have this effect. It was decided, therefore, to attempt surgical ablation of the cranial prostate, despite the fact that the prostate-seminal vesicle complex is located immediately beneath the symphysis pubis and is not easily accessible (Text-fig. 1). The cranial prostate is a small, creamy-white, lobulated body that lies at the caudal end of the seminal vesicle, which has much the same colour and lobulated form (Text-fig. 2). The two organs are intimately bonded by connective tissue and appearances suggest a single structure. The vas deferens and the ducts of the seminal vesicle are also closely associated, so that excision of the cranial prostate demands great care if damage to the seminal vesicle, its ducts and the vas deferens is to be avoided. The caudal prostate surrounds the urethra; it is readily distinguished from the cranial part of the gland by reason of its smooth contour, distinct capsule and pink colour.

In preliminary experiments, three different methods of approach were tested: (a) low abdominal mid-line incision, (b) incision over the pelvis and fracture of the symphysis pubis, and (c) retropubic incision. The first method

* Present address: Gulf South Research Institute, P.O. Box 1177, New Iberia, Louisiana 70560, U.S.A.

$\dagger$ Present address : Department of Dairy Science, College of Agriculture, Louisiana State University, Baton Rouge, Louisiana 70803, U.S.A.

$\ddagger$ Present address: Physiological Laboratory, Downing Street, Cambridge, England. 


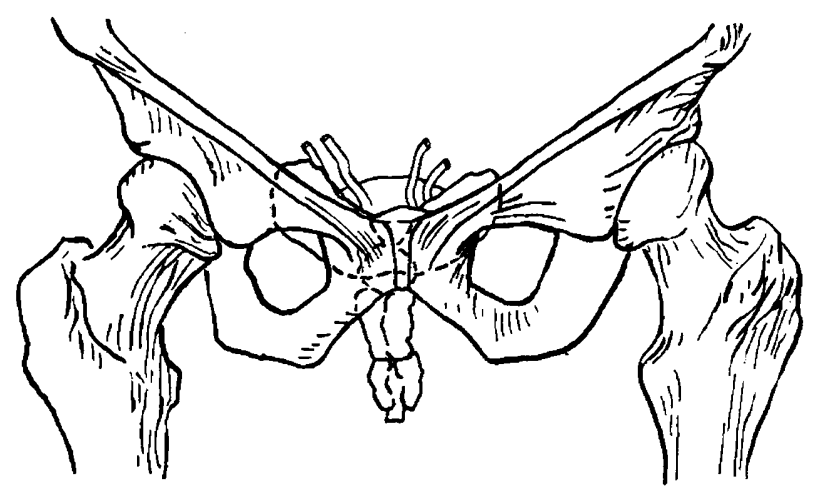

Text-Fig. 1. Diagram showing the relations of the prostate gland and the seminal vesicles to the pelvis in the rhesus monkey.

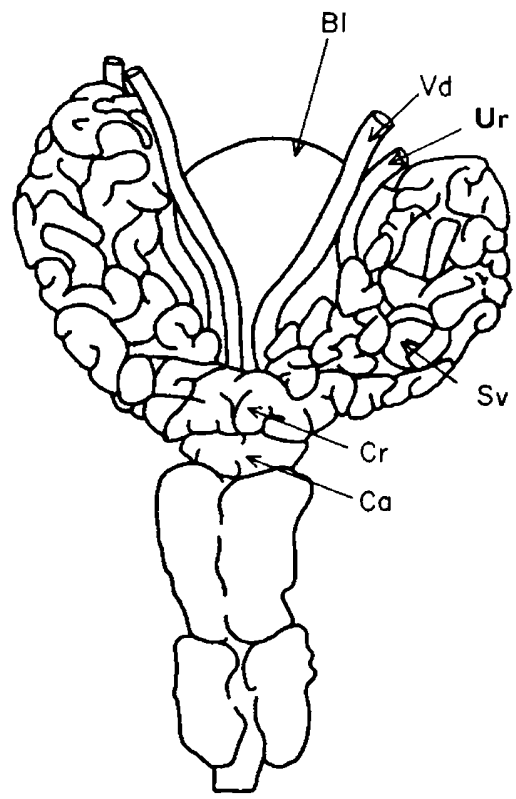

TEXT-FIG. 2. Diagram of the prostate-seminal vesicle complex. Bl, Bladder; $\mathrm{Ca}$, caudal lobe of the prostate; Cr, cranial lobe of the prostate; Sv, seminal vesicle; Ur, ureter; $\mathrm{Vd}$, vas deferens.

\section{TABLE 1}

MEAN VALUES FOR VOLUME, SPERM MOTILITY AND SPERM CONCENTRATION, AND OCGURRENGE OR NON-OGGURRENGE OF COAGULATION, IN SEMEN SAMPLES RECOVERED FROM TWO RHESUS MONKEYS BEFORE AND AFTER GRANIAL PROSTATECTOMY

\begin{tabular}{|c|c|c|c|c|c|c|}
\hline & Animal & $\begin{array}{c}\text { No. semen } \\
\text { samples }\end{array}$ & $\begin{array}{l}\text { Volume } \\
(\mathrm{ml})\end{array}$ & $\begin{array}{c}\text { Motility } \\
(\%)\end{array}$ & $\begin{array}{c}\text { Concentration } \\
\left(\times 10^{6}\right)\end{array}$ & $\begin{array}{l}\text { Coagulation } \\
\text { upon } \\
\text { ejaculation }\end{array}$ \\
\hline $\begin{array}{l}\text { Before cranial } \\
\text { prostatectomy }\end{array}$ & $\begin{array}{l}\mathbf{A} \\
\mathbf{B}\end{array}$ & $\begin{array}{l}3 \\
3\end{array}$ & $\begin{array}{l}1 \cdot 1 \\
1 \cdot 1\end{array}$ & $\begin{array}{l}32 \\
40\end{array}$ & $\begin{array}{l}244 \\
233\end{array}$ & + \\
\hline $\begin{array}{l}\text { After cranial } \\
\text { prostatectomy }\end{array}$ & $\begin{array}{l}\mathbf{A} \\
\mathbf{B}\end{array}$ & $\begin{array}{l}\mathbf{3} \\
\mathbf{3}\end{array}$ & $\begin{array}{l}1.0 \\
0.7\end{array}$ & $\begin{array}{l}53 \\
55\end{array}$ & $\begin{array}{l}212 \\
208\end{array}$ & - \\
\hline
\end{tabular}


provided difficult access to the prostate gland, and the orthopaedic procedure of the second was not justified by the small improvement in ease of access. The third method was most satisfactory from all points of view and was, therefore, adopted.

Under methoxyflorane anaesthesia (with Innovar-Vet pre-anaesthetic medication), the bladder was first emptied by catheterization, the catheter remaining in place to assist subsequently in manipulation and identification of the urethra, and to ensure its patency. The prostate gland was then reached by the retropubic approach, a considerable amount of dissection being necessary to expose the surgical field adequately. Post-surgical recovery was uneventful, healing being complete by about Day 7 . During recovery, the animal was kept in a cage with a low ceiling ( 24 in.) which did not permit standing to full height; in this way excessive stress on the incision during healing was avoided.

Four mature male rhesus monkeys were electrically ejaculated by the method of Roussel \& Austin (1968) each week for 2 months to provide pretreatment material, and were then subjected to cranial prostatectomy. Two weeks later, the weekly semen collection was resumed.

In the first animal to be treated, removal of the cranial prostate was not complete - basilar portions were left intact, because of the difficulty of excision. This animal yielded ejaculates that had virtually the same amount of coagulum as before treatment. In the second animal, the operation was more complete, though some portions of the gland were known to have been left. Semen from this animal contained a soft loose coagulum. The excision in the third and fourth animals was as complete as could be managed, accessibility of the surgical field being increased by the institution of a lumbar-lift position, and in these animals all subsequent ejaculates have been free of the coagulum. The spermatozoa tend to be held in small masses visible under the microscope, but the semen is quite fluid. The volume of material ejaculated is not significantly less than before the operation, nor is any change in sperm motility or concentration evident in these two animals, comparisons being made with the cells in the spontaneously liquifying fractions of pretreatment ejaculates (Table 1).

This investigation was supported by Public Health Service Grants FR 00164 and GM 13226 from the National Institutes of Health.

\section{REFERENCES}

Rousser, J. D. \& Austin, G. R. (1967) Enzymic liquefaction of primate semen. Int. F. Fert. 12, 280. Roussel, J. D. \& Austin, C. R. (1968) Improved electro-ejaculation of primates. F. Anim. Techns Ass. (in press).

VAN Wagenen, G. (1936) The coagulating function of the cranial lobe of the prostate gland in the monkey. Anat. Rec. 66, 411 . 